2. Самооценка // psychology.net URL:

http://psychology.net.ru/dictionaries/psy.html?word=857 (дата обращения: 10.03.2017).

3. Тест «лесенка» (В. Г. Щур) // Стотестов.py URL: http://www.stotestov.ru / (дата обращения: 10.03.2017).

4. Фетискин Н.П., Козлов В.В., Мануйлов Г.М. Социально -психологическая диагностика развития личности и малых групп. - М. : Изд-во Института Психотерапии, 2007. -490 c.

\title{
Обучение английскому языку учащихся младших классов в национальной школе
}

\author{
Кондратьева С.А., студентка, \\ Северо-Восточный федеральный университет, \\ 2. Якутск \\ E-mail: miss.sardaana@bk.ru
}

Научный руководитель: к.и.н., доцент Карсанаева И.Н.

Языковое образование становится важным инструментом успешной жизнедеятельности человека в мультилингвальном и поликультурном мире и значимым средством, формирующим сознание личности. Иностранный язык как одно из средств коммуникации и познания окружающего социума занимает особое место в системе образования в силу своих социальных, познавательных и развивающих функций [1].

Главной задачей обучения иностранному языку в начальной школе является формирование коммуникативной компетенции в единстве с воспитанием уважения к традициям разных народов и готовностью к межкультурному сотрудничеству.

В школах России изучение английского языка осуществляется со второго класса, так как, чем раньше начать этот процесс, тем больше возможностей для достижения высоких результатов. Тем не менее, мною было выявлено следующее противоречие между востребованностью обучения иностранному языку в начальной школе и низкой мотивацией младших школьников к изучению английского языка.

Цель исследования: выявить трудности обучения английскому языку учащихся младших классов в национальной школе.

Задачи:

1. Ретроспективный анализ специальной литературы по данной теме исследования;

2. Определить роль дисциплины «Иностранный язык» в развитии младших школьников;

3. В ходе педагогической практики выявить трудности обучения английскому языку младших школьников в национальной школе.

Многочисленные научные исследования показывают, что у младших школьников нет осознанной внутренней потребности к изучению иностранного языка, но присутствует их природный интерес, любопытство ко всему новому. Следовательно, главной задачей учителя в начальной школе является не только удержание данного 
интереса, но и дальнейшее повышение мотивации школьников к изучению иностранных языков[2].

При изучении иностранного языка в начальной школе стимулируется общее речевое развитие младших школьников, формируются ценностные ориентиры и закладываются основы нравственного поведения в процессе общения на уроке, чтения и обсуждения текстов соответствующего содержания, знакомство с миром зарубежных сверстников с использованием средств изучаемого иностранного языка (через детский фольклор, детскую художественную литературу), а также вырабатывается дружелюбное отношение и толерантность к представителям других стран и их культуре $[3,128 ; 1]$.

Таким образом, существует ряд преимуществ обучения иностранному языку детей раннего возраста:

1) положительное влияние на развитие психических функций: память, мышление, восприятие и воображение;

2) влияние на общие речевые способности ребенка;

3) повышение качества владения родным языком, создание базы для продолжения его изучения в основной школе;

4) более раннее вхождение ребенка в общечеловеческую культуру через общение на новом для него языке.

Вместе с тем, по мнению Сваловой Е. В. при изучении предмета «Иностранный язык» младшие школьники испытывают многочисленные трудности. Это является результатом того, что особенности учащихся младшего школьного возраста при обучении иностранному языку учитываются не в полной мере [4, 159].

В ходе педагогической практики нами установлены следующие основные трудности обучения английскому языку:

1) отсутствие необходимой материальной базы в школе, соответствующих учебников, учебных пособий и специальных словарей;

2) низкая позитивная мотивация у младших школьников;

3) трудности психологического характера (страх, неуверенность в себя);

4) логопедические проблемы и т.д.

Итак, несмотря на все трудности, целесообразно дополнить имеющиеся учебнометодические комплексы творческой составляющей. Кроме того, учителям следует применить такие виды деятельности, которые будут способствовать повышению мотивации у учащихся младших классов в национальной школе.

Исследование будет продолжено в разработке словаря «Саха-русско-английский словарь для учащихся 1-4 классов».

\section{Список литературы:}

1. Кубрак А.А., Баранова О.И. Методы и средства обучения английскому языку в начальной школе [электронный ресурс] // международный студенческий научный вестник: электр.журн.2004. URL: https:/www.scienceforum.ru/2014/761/1708\#

2. Балина Л. Г. Особенности обучения английскому языку в начальной школе // Научно-методический электронный журнал «Концепт». - 2015. - Т. 30. - С. 531-535. URL: http://e-koncept.ru/2015/65177.htm

3. Колесникова И.Л., Долгина О.А. Англо-русский терминологический справочник по методике преподавания иностранных языков/ И.Л.Колесникова - СПб: Изд-во «Русско-Балтийский информационный центр «БЛИЦ»", «CambridgeUniversityPress», 2001. - 224 c. 
4. Свалова Е. В. Особенности обучения иностранному языку учащихся младших классов средней общеобразовательной школы// Педагогическое образование в России. 2014. №6. C.159-162.

\title{
Индивидуализация в малокомплектной школе на уроках физической культуры
}

\author{
Крылов С.А., учитель физической культуры, \\ Хара-Алданская средняя общеобразовательная школа, \\ Таттинский район, с. Хара-Алдан \\ E-mail: oxstarost@mail.ru
}

Исследование посвящено изучению индивидуализации в малокомплектной школе на уроках физической культуры. Физическая культура и спорт являются важным составляющим в жизни каждого человека. Тем более, в нашем современном мире, когда большинство детей в свободное время предпочтут поиграть в планшеты, телефоны, компьютеры, чем пойдут в спортзал.

Индивидуализацию обучения объясняет автор термина В.А. Крутецкий как «ориентация на индивидуально-психологические особенности ученика, выбор и применение соответствующих методов и приемов, различные варианты задания, дозировка домашних заданий» [2].

В педагогическом словаре дается определение индивидуализации обучения как «организация учебного процесса с учетом индивидуальных особенностей учащихся; позволяет создать оптимальные условия для реализации потенциальных возможностей каждого ученика. Индивидуализация обучения осуществляется в условиях коллективной учебной работы в рамках общих задач и содержания обучения» [1, стр. 46]

Напротив, А.А. Кирсанов утверждает, что индивидуализация обучения это широкое понятие процесса обучения. Сюда входят деятельность учителя, деятельность ученика и весь процесс обучения и подготовки.

Далее рассмотрим варианты индивидуализации, которых объединил И.Э. Унт в условные группы:

1) дифференциация обучения, то есть группировка учащихся на основе их отдельных особенностей или комплексов этих особенностей для обучения по нескольким различным учебным планам или программам. Так создаются относительно гомогенные группы (классы, школы);

2) внутриклассная (внутригрупповая) индивидуализация учебной работы (фронтальная, групповая и индивидуальная формы классной работы);

3) прохождение учебного курса в индивидуально различном темпе: или убыстренно (акселерация), или замедленно (ретардация) [3].

Итак, практическая часть исследования предусматривает индивидуализацию обучения в малокомплектной школе во время уроков физической культуры. В связи с глобальной урбанизацией, в сельских школах с каждым годом все меньше детей, молодые родители стремятся переехать в город. Исходя из этого в селах очень много малокомплектных школ. А в малокомплектной школе наряду с этой проблемой, мы сталкиваемся еще с ненаполняемостью классов. В каждом классе по 4-5-6 детей. 